Canadian University Music Review

Canadian University Music Review

Revue de musique des universités canadiennes

\title{
When Women Play: The Relationship between Musical Instruments and Gender Style
}

\section{Ellen Koskoff}

Volume 16, numéro 1, 1995

Voices of Women: Essays in Honour of Violet Archer

Voix de femmes : mélanges offerts à Violet Archer

URI : https://id.erudit.org/iderudit/1014419ar

DOI : https://doi.org/10.7202/1014419ar

Aller au sommaire du numéro

Éditeur(s)

Canadian University Music Society / Société de musique des universités canadiennes

ISSN

0710-0353 (imprimé)

2291-2436 (numérique)

Découvrir la revue

Citer cet article

Koskoff, E. (1995). When Women Play: The Relationship between Musical Instruments and Gender Style. Canadian University Music Review / Revue de musique des universités canadiennes, 16(1), 114-127.

https://doi.org/10.7202/1014419ar
Résumé de l'article

In many societies, musical roles are divided along gender lines: women sing and men play. Men also sing and women sometimes play; yet, unlike men, women who play often do so in contexts of sexual and social marginality. This essay surveys the literature on women's use of musical instruments in a variety of social and cultural contexts and presents some contemporary anthropological theories regarding the interrelationship between social structure and gender stratification. The author concludes that women's use of musical instruments is related to broader issues of social and gender structure, and that changes in the ideology of these structures often reflect changes that affect women as performers.
All Rights Reserved @ Canadian University Music Society / Société de musique des universités canadiennes, 1995
Ce document est protégé par la loi sur le droit d'auteur. L'utilisation des services d'Érudit (y compris la reproduction) est assujettie à sa politique d'utilisation que vous pouvez consulter en ligne.

https://apropos.erudit.org/fr/usagers/politique-dutilisation/ 


\title{
WHEN WOMEN PLAY: THE RELATIONSHIP BETWEEN MUSICAL INSTRUMENTS AND GENDER STYLE
}

\author{
Ellen Koskoff
}

In many societies, musical roles are divided along gender lines: women sing and men play. Of course, men also sing, and women sometimes play; yet, unlike men, women who play often do so in contexts of sexual and social marginality. This essay surveys the literature on women playing musical instruments in a variety of social and cultural contexts. It then presents some contemporary anthropological theories regarding the interrelationship between social structure and gender stratification that can be useful in understanding this data in the broader perspective of gender relations. ${ }^{1}$ I will, for now, regard women's performance on musical instruments, or the lack thereof, as an indicator of the gender style of a given society, for although all performance may be regarded as a locus of power, performance on musical instruments is often bound up with cultural notions of gender and control in ways that vocal performance is not.

First, some preliminary remarks concerning gender, musical instruments, and cross-cultural surveys. The term "gender" is being used here to define a socially constructed category (i.e., man and woman) and is distinguished from "sex," the biological category of one's birth (i.e., male and female). Further, although all societies recognize differences between the two sexes and often use these as the primary bases for the division of labour in economic, ritual, and other domains, gender categories are often quite fluid, with so-called "masculine" or "feminine" behaviours appearing to a certain degree in both sexes."

The term "gender ideology" has been used by Ortner and Whitehead, ${ }^{3}$ among others, to denote the conceptual and valuative framework that underlies and

1 For a more complete discussion of the literature on women's vocal and dance traditions, see Ellen Koskoff, ed., Women and Music in Cross-Cultural Perspective (Westport, Conn.: Greenwood Press, 1987).

2It may seem obvious that male children become men and female children women; yet, examples of the cross-interplay between these two categories exist. For example, it is well-known that among certain Native American groups a child of one biological sex is occasionally raised to become the opposite gender, so that, for example, a young female, raised to be a "man," will take on all of the attributes of masculine behaviour, including dress and gender-based roles, such as hunting. She may even marry a female, although it is unclear whether such couples engage in homosexual behaviour; see Paula Gunn Allen, The Sacred Hoop (Boston: Beacon Press, 1986), 198-200. These so-called mid-gender roles are fairly common in many societies, and their connection to music performance awaits further study.

3 Sherry Ortner and Harriet Whitehead, "Introduction: Accounting for Sexual Meanings," in Sexual Meanings: The Cultural Construction of Gender and Sexuality, ed. Sherry Ortner and Harriet Whitehead 
structures appropriate behaviours for women and men. Ideologies may be codified as religious, moral, or legal justifications for gender relations. ${ }^{4} \mathrm{Al}-$ though gender roles are based to a certain degree on biological categories, it is the value given to one gender over the other that promotes a certain socially accepted gender style, theoretically ranging from relatively equal autonomy and value for both men and women (complementarity), to a lack of equality in both autonomy and value (gender stratification).

Musical instruments are defined here simply as material objects outside the body (perhaps connected to the body) that are used in performances of music, dance, ritual, and ceremony, however culturally defined, or to accompany such performances. Clapping, slapping one's thighs, snapping fingers, or other rhythmic accompaniment that uses one's own body will not be considered here.

Concerning cross-cultural surveys, it goes without saying that social contexts for performance vary widely across cultures and time, as do the relative distribution and significance of instruments and instrumental performance. Making generalizations about gender and musical roles is therefore fraught with difficulties. Native perspectives, individual exceptions, and the complexities of everyday life tend to be glossed over or ignored in such generalizations, and they can often veer towards the glib. Yet, there is value in the cross-cultural survey, for certain patterns emerge from this perspective that can help to clarify relationships between men, women, and music, and the relative value given to those who engage in musical activity.

\section{Contexts for Performance}

Descriptions of women performing on musical instruments are fairly rare. Indeed, in a rough survey of various ethnomusicological journals, I could find no more than $10 \%$ of the total literature referring to women performers at all, and of that $10 \%$, only about $20 \%$ made a passing reference to women performing on an instrument. ${ }^{5}$

I have grouped the descriptions of women's instrumental performances that I found into four basic (at times, overlapping or related) socio-musical contexts that can serve as appropriate categories for discussion: (1) the context of the court; (2) the context for courtship; (3) ritual contexts, especially those of healing, initiation, burial, or those involving role-reversals, where inter-gender

(Cambridge: Cambridge University Press, 1981).

4Charlotte G. O'Kelly and Larry S. Carney, Women and Men in Society: Cross-Cultural Perspectives on Gender Stratification, 2nd ed. (Belmont, Calif.: Wadsworth Publishing, 1986), 93.

5 I surveyed all of the issues of Ethnomusicology, Journal of the International Council for Traditional Music, World of Music, African Music, Latin American Music Review, and Asian Music. Still hunting, I spent an afternoon leafing through the three-volume set of The New Grove Dictionary of Musical Instruments, ed. Stanley Sadie (London: Macmillan Publishing, 1984), and found only 40 photographs picturing women performers, roughly $10 \%$ of the total number of photographs of live performances. I did not include in this survey photographs of instruments alone where the sex of the usual performer was unknown. Nor did I include photographs of paintings or other works of art picturing performers. It is interesting to note that within this last category, a much higher percentage (ca. 30\%) pictured women as performers (reality? or perhaps the artists' conception of the "idealized" woman?) Finally, there was not one photograph picturing a female performer on a Western classical instrument. 
relations are protested or mediated; and (4) the context of everyday life, involving musical performances accompanying food preparation, child care, or perhaps self-entertainment. Each of these contexts is related to, perhaps structured by, specific gender ideologies, so that examining such contexts more fully can reveal much about the range of gender styles that exists cross-culturally.

\section{The Context of the Court}

Western classical music and many of the music traditions of the Middle East, Asia, and Africa can be described as having evolved, in part, from a court tradition, where musicians for many centuries have been supported for and by a small, elite, ruling class, dominated by males. Historically, most musicians (both male and female) in this social context suffered somewhat from a low social status, yet only performances by women are described as linked to their social-sexual roles, primarily as courtesans.

There are many passing references to female instrumental performers attached to the great courts of Europe and Asia; notable among them are descriptions of the devadasi in India by Jennifer Post, of the qaina in Tunisia by JaFran Jones, of the geisha in Japan by William Malm, of the mahori ensemble in Thailand by David Morton, and an especially full treatment of Sudanic Africa by Jacqueline Dje Dje. ${ }^{6}$ Two examples will be discussed here more fully, as they highlight the ambiguous and often powerful role of the courtesan/musician. Anthony Newcomb, in his article, "Courtesans, Muses or Musicians? Professional Women Musicians in Sixteenth-Century Italy," traces the growth of the concerti di donne, the all-female performing ensembles of both singers and instrumentalists (especially lute, viol, and harp) attached to the Northern Italian courts. Newcomb suggests that over a period of thiry years (from 1580 to 1610) the status of these performing women rose from that of a generalized courtesan to a specialized professional musician. These women, frequently chosen from the rising merchant class, were most often musically gifted as children, having received musical training from male family members. Although skirting the issue of their sexual role, Newcomb fully documents their musical careers with (often droll) references to their frequent marriages or to their single status, which marked them as "remarkable renegade(s) to be looked at, applauded, but not included in polite society."

Such women, although not technically courtesans, were nevertheless associated with courtly life, seen as a "neo-pagan world [where] physical beauty was regarded as divine, and sensuality came not far behind." ${ }^{8}$ The term courtesan-

6See Jennifer Post, "Professional Women in Indian Music: The Death of the Courtesan Tradition," in Women and Music in Cross-Cultural Perspective, 97-109; L. JaFran Jones, "A Sociohistorical Perspective on Tunisian Women as Professional Musicians," ibid., 69-84; William P. Malm, Japanese Music and Musical Instruments (Rutland, Vt.: Charles E. Tuttle, 1959); David Morton, The Traditional Music of Thailand (Berkeley: University of California Press, 1976); and Jacqueline Cogdell Dje Dje, "Women and Music in Sudanic Africa," in More Than Drumming, ed. Irene V. Jackson (Westport, Conn.: Greenwood Press, 1985).

7 Anthony Newcomb, "Courtesans, Muses or Musicians? Professional Women Musicians in Sixteenth-Century Italy," in Women Making Music: The Western Art Tradition, 1150-1950, ed. Jane Bowers and Judith Tick (Urbana: University of Illinois Press, 1986), 103.

8 Georgina Masson, Courtesans of the Italian Renaissance (London: Secker \& Warburg, 1975), 6. 
similar in meaning to geisha in Japan, devadasis in India and qaina in the Middle East-arose in fifteenth-century Italy and was rapidly adopted because, as Georgina Masson states, "it would have been awkward to refer to these beautiful, much courted, and often gifted women as whores. With its ugly connotations, 'whore' would have seemed in Renaissance eyes to be a name totally unsuited to a charming woman who made a profession of giving pleasure." 9 That these women were privileged is not surprising. Like most women of their class, they were usually dependent economically and socially upon men-often one, stable patron-yet, unlike their less privileged counterparts, many were highly educated, especially in music and literature, and were thought of as witty and intelligent companions. Some even achieved a remarkable degree of economic and sexual freedom and status.

Byong Won Lee, in an article describing the role and status of professional female entertainers in Korea, suggests a similar pattern of social, sexual, and economic interaction. Historically, the kisaeng were chosen from the lowest social castes, their status often rising as a result of concubinage. By the eighteenth century three classes of kisaeng had developed that were graded on a scale of relative sexual behavior, ranging from "true kisaeng," those who were trained in the refined, courtly traditions and were supported economically by one patron, to prostitutes, who performed folksongs and provided sexual pleasures for many. By the mid-twentieth century, however, these distinctions had all but disappeared, and two classes of female performers remain: "governmental performers" or "researchers" who perform at official banquets and receptions (musically, if not sexually, the "true kisaeng" of earlier generations) and kisaeng, a term now used to designate prostitutes who perform most often in designated entertainment quarters. ${ }^{10}$

\section{The Context for Courtship}

A second context, related to that of the first, provided other women of the upper and middle classes (those with "unblemished reputations"), some opportunity for instrumental as well as vocal performance. Certainly, from the eighteenth century to the present, again in the areas of the world that supported a court system, the home, a semi-private, protected environment, became the most important context for women performers. Unmarried women, often viewed as property to be transferred from father to husband, perfected skills there that would make them desirable to potential mates; males, in positions of economic and social power (relative to women of their class), generally had access to musical training and to public, even professional environments for musical performance.

Though the literature here is scanty, musical instruments such as the koto, shamisen, and biwa in Japan, the piano and violin in Europe, and the kulintang in the Philippines became associated with women, primarily in the context of

9Ibid., 5-6.

10Byong Won Lee, "Evolution of the Role and Status of Korean Professional Entertainers (Kisaeng)," World of Music 21, no. 2 (1979): 80-81. 
courtship, during which the performers could display idealized notions of proper female behavior and "feminine accomplishments." Judith Tick, for example, describes nineteenth-century parlour performances on the piano, harp, and guitar as flourishing in Europe and the United States, where such instruments were deemed proper for domestic female entertainment as they "required no facial exertions or body movements that interfered with the portrait of grace that the lady musician was to emanate."11 In referring to the history of the Japanese koto, William Malm states that in contrast to the shamisen, with its association to the "turbulent excitement which the entertainment districts of Edo represent," the koto "entered the home as an accomplishment for the daughters of the rising commercial class as well as those of the nobility." 12

Perhaps one of the best descriptions of a female performance tradition seen in the context of courtship is that found in Usopay Cadar's article, "The Role of Kulintang Music in Maranao Society." The kulintang, a set of tuned gongs, is both a traditional instrument of the Philippines and the name given to the ensemble that employs it as the main elaborating melody instrument. It is traditionally played by young, unmarried women: "Men are considered too masculine, too expressive, and too stiff to be able to play the melody part. Nevertheless, there are a few men who play the kulintang, but they are either feminized or regarded as people endowed with extramusicality."13

Kulintang performances usually take place in the home during a gathering of friends, relatives, or special visitors, and everyone is expected to perform at some time during the evening, although elaborate social rules exist as to the order of performers according to age, experience, and ability. Cadar beautifully describes the entrance of the kulintang performer during the serious or formal aspect of the performance. After having waited a proper interval of time, so as not to have seemed impatient or greedy for attention, "the kulintang player stands, leaves the section for women and walks towards the instrument. On her way, she may execute the Maranao traditional walk, using her left arm to hold the malong (loose tubular skirt) while her right arm freely and gracefully swings." 14 But even more interesting is Cadar's suggestion that the music is actually an encoding of inter-gender relations during courtship, marked by the teasing, yet discrete, flirtation characteristic of Philippine courtship practices. Cadar's description of interplay, both musical and sexual, between the kulintang player and the drummer (always male) makes this connection clear. ${ }^{15}$

11 Judith Tick, "Passed Away Is the Piano Girl: Changes in American Musical Life, 1870-1900," in Women Making Music, 327. See also Beth Miller, "Eliza Ridgely of Hampton: New Perspectives on the Piano Girl" (graduate paper, New York University, 1988).

12Malm, Japanese Music and Musical Instruments, 165.

13Usopay H. Cadar, "The Role of Kulintang Music in Maranao Society," Ethnomusicology 17, no. 2 (1973): 239.

14 Ibid., 243.

15Sarah Weiss, in a personal communication, has also described this sort of musical flirtation among female gender players in Java. 


\section{Ritual Contexts}

Ritual contexts, especially those surrounding shamanism, burial, initiation, and rituals where role-reversal is a major theme provide other, if limited, opportunities for women performers. Consider, for example, the dominant role of men in the major religious and medical institutions of the world-as musicians, priests, cantors, or doctors. Women's ritual activities usually take place outside of these contexts. Gilbert Rouget, in his Music and Trance, describes a female shaman tradition among the Araucan of southern Chile, where participants induce trance through dancing and drumming. ${ }^{16}$ Martha Binford in Mozambique, Jacqueline Dje Dje in Sudanic Africa, and Laurel Kendall and Halla Pai Huhm in Korea state that shamans commonly use drums and cymbals attached to their bodies to induce trance. ${ }^{17}$

Barbara Hampton, in her article, "Music and Ritual Symbolism in the Ga Funeral," describes a genre of songs, adowa, performed solely by women. These songs are accompanied by rattles and bells and by the pamplo, bamboo tubes used in place of the traditional drums found in other ensembles. Hampton states that monosex grouping among the $\mathrm{Ga}$, a social fact reflected in a music practice, is grounded in beliefs in the contamination of ritual objects by menstruating women: "Drums belong to this category of ritual objects and are not performed by ... women."18

Hugo Zemp among the Senufo, Jacqueline Dje Dje among the Hausa, and John Blacking among the Venda, however, point to a strong drumming tradition for women. ${ }^{19}$ Blacking, in describing the domba, a girls' initiation dance, gives clues as to the sexual symbolism of the drums performed throughout this ceremony:

... the heartbeat of the unborn baby is represented by the beat of the drumstick on the centre of the skin of the bass drum: the drum represents the head of a child and the centre of its skin, the baby's fontanelle. Each performance of the domba in the morning and late at night symbolizes both in movement and in music the mother's womb and the sacred act of love whose repetition is believed to build up the fetus. ${ }^{20}$

16Gilbert Rouget, Music and Trance: A Theory of the Relations Between Music and Possession, trans. Brunhilde Biebuyck (Chicago: University of Chicago Press, 1985), 125. It is interesting to note that the drum is almost universally performed by males. Aside from passing references to all-female drumming groups in Africa, the shaman tradition was the only context where I found consistent references to women drumming.

17 See Martha B. Binford, “Julia: An East African Diviner," in Unspoken Worlds: Women's Religious Lives in Non-Western Cultures, ed. Nancy Auer Falk and Rita M. Gross (San Francisco: Harper and Row Publishers, 1980); Dje Dje, "Women and Music in Sudanic Africa"; Laurel Kendall, Shamans, Housewives, and other Restless Spirits: Women in Korean Ritual Life (Honolulu: University of Hawaii Press, 1985); Halla Pai Huhm, Kut: Korean Shamanist Rituals (Elizabeth, N.J.: Hollym International Corporation, 1980).

18Barbara L. Hampton, "Music and Ritual Symbolism in the Ga Funeral," Yearbook for Traditional Music 14 (1982): 76.

19 See Hugo Zemp, "L'origine des instruments de musique: 10 récits Senoufo (Afrique occidentale)," World of Music 18, no. 3 (1976): 3-18; Dje Dje, "Women and Music in Sudanic Africa"; John Blacking, "The Value of Musical Experience in Venda Society," World of Music 18, no. 2 (1976): 23-28.

20Blacking, "The Value of Musical Experience in Venda Society," 23-24. 
Rituals that involve a theme of gender role reversal also provide opportunities for women's instrumental performance. During such rituals, women (and men) take on stereotyped behaviours, dress, language, and musical style associated with the opposite gender, often for the purpose of protesting or mediating antagonisms. Victor Turner has described the process of ritual role and status reversal, characterizing this state as one of "liminality" or marginality, for during such rituals, participants are not seen as fixed in any permanent social position, but rather are in a dynamic state, moving temporarily from one status level to another. ${ }^{21}$

The literature describing gender role-reversal is fairly large, and women's ritual practices in those contexts are well-documented..$^{22}$ One vivid example will suffice here: in an article describing women's love rituals (yilpinji) in Central Australia, Diane Bell states that their performance is linked to Aboriginal notions of women's control of the land and of human emotions. Songs and dances connected with these rituals are frankly sexual, with women enacting both male and female roles. Intercourse is often described textually or simulated in dance, where the participants use musical instruments (rhythm sticks) as mock penises. ${ }^{23}$

\section{The Context of Everyday Life}

Outside the ritual domain, opportunities for performances on musical instruments exist in everyday life for a variety of reasons including, simply, selfamusement. Ken A. Gourlay among the Kagoro of Nigeria, David Rycroft among the Zulu, and Jacqueline Pugh-Kitingan among the Huli of Papua New Guinea, all describe female performance genres, both in association with women's song performance or as solo traditions for the purpose of self-entertainment. ${ }^{24}$ Further, Margaret Kartomi in Java describes women's rice-stamping music performed with hollow tubes, which eases the tedium of food preparation. ${ }^{25}$ Finally, in an article devoted to women as primary culture bearers in Afghanistan, Lorraine Sakata describes the chang, a jew's harp performed by women. She notes, however, that when played by a woman, it is not considered a "real" instrument, and when played by a man, the performer is usually old, that is, not considered a "real" man. ${ }^{26}$ 1969).

21 Victor Turner, The Ritual Process: Structure and Anti-Structure (Chicago: Aldine Publishing,

22See for example Turner, The Ritual Process: Structure and Anti-Structure; Ellen B. Basso, A Musical View of the Universe: Kalaoalo Myth and Ritual Performance (Philadelphia: University of Pennsylvania Press, 1985); Marina Roseman, "Inversion and Conjuncture: Male and Female Performance among the Temiar of Peninsular Malaysia," in Women and Music in Cross-Cultural Perspective, 131-49.

23Diane Bell, "Women's Business is Hard Work: Central Australian Aboriginal Women's Love Rituals," Signs 7, no. 2 (1981): 323.

24Ken A. Gourlay, "Men, Women and Music" (graduate paper, New York University, 1988); David Rycroft, "The Zulu Bow Songs of Princess Magogo," African Music 5, no. 4 (1975): 41-97; Jacqueline Pugh-Kitingan, "Huli Language and Instrumental Performance," Ethnomusicology 21, no. 2 (1977): 205-32.

25 Margaret Kartomi, "Music and Trance in Central Java," Asian Music 13, no. 2 (1982): 163-208.

26Hiromi Lorraine Sakata, "Hazara Women in Afghanistan: Innovators and Preservers of a Musical Tradition," in Women and Music in Cross-Cultural Perspective, 86-87. 


\section{The Symbolism of Musical Instruments}

One cannot help but notice that women's opportunities to perform on musical instruments are limited, relative to those of men, across cultures and time. Of course, it may be that ethnographers and historians have ignored women performers or have been denied access to performance situations. Nevertheless, it seems that women simply do not play instruments to the same degree as do men. If this is so, why? Some clues lie in the symbolic content of musical instruments and their use and in metaphors for musical sound as expressed by native informants that conceptually link music to other cultural domains. Unfortunately, many of the works cited above, making only passing references to women performers, do not provide adequate information on the symbolic content of the instruments described, so that generalization is somewhat inhibited.

The symbolic content of musical instruments, often expressed through gender-based metaphors, frequently discloses complicated and ever-changing relationships between men and women. For example, Marina Roseman, in her study of the Temiar of Peninsular Malaysia, discusses metaphors for sound that link the woman's bamboo stamping tubes with drum strokes, a two-tiered fish trap, and the rainbow. She points out that the tubes comprise a "father," a longer, lower-pitched tube played so that its sound decays naturally, and a "mother," a shorter, higher-pitched tube with a short sound duration; likewise, the rainbow is said to have a "short whitish section near the ground (the mother) and a long arching colored midsection (the father)."27 Blacking's description of the woman's drum used in the Venda girl's initiation dance as a metaphor for sexual intercourse and babies, Dje Dje's example of the imzad, whose performance and musical sounds symbolize the soft female voice, and Tick's description of the piano as the quintessential "female" instrument are a few more that can be cited here.

In another example, taken from an unpublished paper on contemporary attitudes towards women in orchestras, Elizabeth Aureden asked both male and female members of the Eastman School of Music's student orchestra to rate standard orchestral instruments on a scale from "most feminine" to "most masculine." One interesting result was that most of the respondents placed most of the instruments on the "masculine" side, with percussion, tuba, and saxophone most often at the extreme pole. Far fewer instruments were placed on the "feminine" side, but in almost all cases, the flute and harp were at the extreme female pole. ${ }^{28}$

Perhaps another way to approach the question of why women appear not to play may lie in the use of musical instruments as instruments of power and

27Marina Roseman, "Inversion and Conjuncture: Male and Female Performance among the Temiar of Peninsular Malaysia," in Women and Music in Cross-Cultural Perspective, 142.

280ne student, as she completed her graph, commented: "I've always imagined the flute to be the most feminine. In grade school, if a boy played the flute, he was a laughing stock. ... This is kind of funny-most everything is on the masculine side. Society tells us what instruments to play, just like boys play with cars and girls with dolls." Elizabeth Aureden, "Women in Orchestras: Changing or Disguised Faces?" (graduate paper, University of Rochester, Eastman School of Music, 1983), 9. 
control. I refer especially to ritual performances by adult males, who use instruments to intimidate, coerce, or otherwise control women and, in some cases, children; often these are instruments whose origins are symbolically linked to women. Many detailed descriptions of this use of instruments exist in the literature ${ }^{29} \mathrm{Here}$, women and children are prohibited from playing instruments or watching performances, and threats of extreme punishment, such as gang-rape or death by insect-stinging are common. In these instances, the instruments and the sounds they produce are agents of control that one group of people (adult males) uses to subordinate others (uninitiated males, and all women).

\section{Toward a Theory of Gender and Instrumental Performance}

What appears to be central to all of the descriptions presented so far is the notion that musical instruments are everywhere linked to gender ideologies, however culturally constructed and maintained. Such ideologies inform much of the symbolic content of musical instruments and their sounds, prescribe who shall and who shall not play, and under what circumstances performances will occur. Thus, on the one hand it appears that instruments and the sounds of instruments associated with men, with "masculinity" or with male performance, are frequently linked to economic, ritual, and sexual power. Such instruments are often used by men to limit, control, or coerce women; or women may use them when confronting, borrowing, or protesting such power. For men, this constellation of music and power may take the extreme form of actual or threatened punishment, as when a woman in Papua New Guinea or Central Brazil is raped or beaten if she performs on a forbidden instrument. Or it may take the form of lack of access, as when a young girl in Iowa or New York is "discouraged" from performing on a "masculine" instrument, such as the drum or tuba. Women who defy their socially accepted roles and perform on male-associated instruments risk punishment, social ostracism, or devaluation. On the other hand, instruments, their sounds, and performance contexts, associated with women tend to be devalued in many societies, that is, seen as associated with children or "amateur" and/or linked to women's marginal social and sexual status, and performance by males on these instruments or in these contexts can result in similar social punishments as for women.

A deeper understanding of the unequal division of musical roles results when one examines the complex interrelationships between these symbolic associations, a given society's gender structure, and its social structure. Much recent

29 See especially Ken A. Gourlay, Sound-Producing Instruments in Traditional Society: A Study of Esoteric Instruments and Their Role in Male-Female Relations, New Guinea Research Bulletin, no. 60 (Port Moresby: The Australian National University, 1975); Ellen B. Basso, "Musical Expression and Gender Identity in the Myth and Ritual of the Kalapalo of Central Brazil," in A Musical View of the Universe: Kalaoalo Myth and Ritual Performance, 163-76; Yolanda Murphy and Robert Murphy, Women of the Forest, 2nd ed. (New York: Columbia University Press, 1985); Carol E. Robertson, "Power and Gender in the Experiences of Women," in Women and Music in Cross-Cultural Perspective, 225-44; Colin M. Turnbull, The Forrest People, (New York: Simon and Schuster, 1981); and Jonathan Hill, "Kamayura Flute Music: A Study of Music as Meta-Communication," Ethnomusicology 23, no. 3 (1979): 417-32; among others. 
feminist-oriented scholarship has adopted a perspective that regards gender stratification as an outgrowth of patriarchy, notions of private property, and capitalism..$^{30}$ Recent scholars like Michelle Rosaldo, Gerda Lerner, Joan KellyGadol, and Peggy Reeves Sanday, among others, have developed a theory that examines the degree of gender stratification in relation to various modes of economy. ${ }^{31}$ This theory proposes positive correlations between the degree to which public and domestic spheres are merged and the lack, or heightened instance of, gender stratification. Such a theory can be applied cross-culturally to help explain the wide variety of gender styles noted in the ethnographic literature.

At one end of the continuum are societies, such as forager (hunting and gathering) or horticultural societies, where there is little distinction between domestic and public spheres. However those domains are conceptualized by insiders to the culture, activities in both spheres are fairly equally shared by both men and women. There is little or no notion of private property, ownership, or social class. Such societies are characterized by a complementarity between the sexes, that is, both men and women, although performing different work, rituals, and other social activities, are valued equally, and neither sex is placed under the authority of the other. Some societies at this end of the continuum are matrilineal and/or matrilocal, adding to the strength of women's social and familial ties. In addition, many of these societies have had little contact with Western technology or with the value systems surrounding technology that tend to polarize male and female labour.

Toward the other end of the continuum are agrarian societies or those recently-developed capitalist societies with an agrarian past, where there is a sharp differentiation between public and domestic spheres. In these economies women "steadily lose control over property, products and themselves as surplus increases, private property develops and the communal household becomes a private economic unit." 32 Societies at this end tend to be patrilineal, patriarchal, and characterized by a higher degree of technology, materialism, and class stratification. Gender relations are marked by a strict separation of the sexes and rigid rules governing appropriate behaviours, where women, seen (at least historically) as property, have less or no access to public institutions, marriage negotiation, reproductive rights, or divorce. Accompanying such social behaviour is an unequal evaluation of the sexes that places women in the subordinate position. ${ }^{33}$

30See Frederick Engels, The Origin of the Family, Private Property and the State, ed. Eleanor Burke Leacock (1942; reprint, New York: International Publishers, 1972).

31 Michelle Zimbalist Rosaldo, "Woman, Culture and Society: A Theoretical Overview," in Woman, Culture and Society, ed. Michelle Zimbalist Rosaldo and Louise Lamphere (Stanford: Stanford University Press, 1974); idem, "The Use and Abuse of Anthropology: Reflections on Feminism and Cross-Cultural Understanding," Signs 5, no. 2 (1980): 389-417; Gerda Lerner, The Creation of Patriarchy (New York: Oxford University Press, 1986); Joan Kelly-Gadol, "The Social Relation of the Sexes: Methodological Implications of Women's History," Signs 1, no. 4 (1976): 809-23; Peggy Reeves Sanday, Female Power and Male Dominance: On the Origins of Sexual Inequality (Cambridge: Cambridge University Press, 1981).

32Kelly-Gadol, "The Social Relation of the Sexes," 819.

33 Peggy Reeves Sanday has characterized societies at the "merged" end as "inner-oriented," that is, 
There has been some criticism of Rosaldo's theory of public and domestic spheres, perhaps more for its misappropriation than for its inherent structure. Actually, there are two continua present in Rosaldo's theory. The first distinguishes "public" from "domestic"; the second indicates the degree to which a society merges or separates these spheres. Further, as both men and women exist in both spheres, it is incorrect to equate women solely with the domestic and men with the public; rather, one should look to the degree to which one gender is valued over the other and has control and authority over the other, how the spheres overlap, and, finally, how such issues are negotiated in ritual and everyday life. Thus, the dichotomization of public and domestic spheres proposed by Rosaldo was never to be seen in isolation, but rather as a theoretical construct that allows the complexities of inter-gender relations to be better elucidated. ${ }^{34}$

The literature cited above suggests a theory that relates women's use of musical instruments to broader issues of social and gender structure. ${ }^{35}$ In societies where public and domestic spheres are relatively merged, there appears to be a higher degree of, and more value for, women's instrumental performance than in those societies where the domestic and public spheres are more highly differentiated. This is not surprising, as in such societies, women, in general, have more economic and political power as well as sexual freedom, and gender ideologies tend to support and value women's social position to a relatively greater degree. Therefore, in such societies, rituals surrounding initiation, healing, and those of gender role reversal, where women's power is most evident and effective, provide the richest opportunities for women's instrumental performance. Descriptions cited here, such as those of the Temiar (Roseman), Australian Aboriginals (Bell), and various African societies (Blacking, Dje Dje, Hampton, etc.) seem to bear this out.

In societies characterized by a heightened gender stratification-those that have supported a court/class system and have inherited the gender attitudes of a pastoral or agrarian past-contexts for women's instrumental performances are most often linked to their potential as sexual partners, either as wives or as courtesans, where even access to musical instruments-considered, like the women themselves, as property and thus to be "granted" to women-is severely limited. Again, the descriptions of Western and Asian classical traditions by Newcomb, Neuls-Bates, Malm, Morton, etc. and of parlour traditions by Tick, Cadar, and Miller seem to bear this out.

focusing on the importance of female fertility and reproductive powers, while societies at the opposite end are characterized as "outer-oriented," focusing on power, domination and killing; see Female Power and Male Dominance: On the Origins of Sexual Inequality (Cambridge: Cambridge University Press, 1989), 3-5.

34 Rosaldo herself addressed some of these issues in an article, "The Use and Abuse of Anthropology," 389-417.

35 As the ethnomusicological literature is not always uniform in the quantity or quality of data concerning instrument symbolism, gender relations, or in describing the socio-musical contexts of women's performances, this theory, although plausible, must remain in the realm of conjecture. 
Two qualifications must be mentioned here. The first involves the issue of the idealization of gender roles, often stated or acted out in ritual, myth and/or metaphor, versus the reality of everyday existence, where relations between the sexes are often far more complicated and volatile. For example, the literature on the male use of musical instruments as tools for asserting power and coercing women frequently states that these stereotyped rules for behaviour are seldom adhered to by either men or women in their everyday life. Similarly, in the literature on the courtesan tradition, it is often suggested that individual women were occasionally in positions of considerable power and that all-female environments that fostered musical performance not only reflected the subordinate sexual and economic status of women, but were also real, everyday environments that encouraged female bonding and the development of political power. ${ }^{36}$

The second qualification concerns the issue of age and its effect upon women as instrumental performers. Young, unmarried, uninitiated girls and older women, those past childbearing years, are thought of in many societies to be in a non-threatening, perhaps marginal state. Pre-menstrual women, who are not yet settled in their adult status (often the only status that defines them as social beings), and post-menopausal women, who are no longer believed to be sexually active, cannot be threatening to the social/sexual order. Frequently, restrictions regarding instrumental performance are lifted for these females. For example, much of the literature on female shamans describes their accumulation of power as they grow older. This is linked not only to their advancing age and to the acquisition of knowledge, but also to their passing out of a polluted or contaminated state, where their power may be able to disrupt, but not destroy, the social order. Similarly, in the court context, where women who are sexually active are the main performers, their sexual status is heightened, and performance can be regarded as a metaphor for sexual relations. Once again, such women can be seen as existing in a marginal social state, whether they are upper-middle class young maidens or courtesans. ${ }^{37}$

If the theory suggested above is correct, then changes in social structure and gender ideology will also be reflected in changes for women performers. Has this, in fact, occurred? Some final examples of newly emerging performance contexts for women do support this notion. Jennifer Post, in her article, "Professional Women in Indian Music: The Death of the Courtesan Tradition," describes the end of the singer/dancer tradition that had flourished in India for centuries. By the late nineteenth century, British notions of proper gender relations had effectively destroyed this tradition, yet at the same time had opened up new opportunities for women's instrumental performance within the more highly regarded genres of classical music. Early in the twentieth century it became fashionable for women, especially of the upper classes, to study instru-

36For an especially good discussion of this point, see Carol E. Robertson's cross-cultural examination of music and power, "Power and Gender in the Experiences of Women," 225-44.

37Frequently, once these women marry, that is, truly settle in the adult social world, they abandon musical performance. 
ments, such as the vina or sarod, instruments associated with the previously male-dominated performance repertoire. Now it is not uncommon to hear a female player, although to my knowledge, women are not yet drummers. Sarah Weiss, in an unpublished paper "Gender and Gender," 38 also notes recent changes among contemporary Javanese women, who have formed all-female gamelan groups, called $i b u$-ibu that regularly perform on the radio.

Carol Neuls-Bates discusses similar developments in Western Classical music in the United States during the period $1925-45 .{ }^{39}$ Post-war prosperity and changing roles for women allowed for more performance opportunities. She traces the growth of the all-female orchestra (often conducted by men) to the "mixed" orchestras of the forties, where, although accepted somewhat reluctantly, women still faced powerful discrimination that was only eased in the 1960 s with the advent of screened auditions. ${ }^{40}$ Certainly, today, we see many more female performers in major orchestras, although the percentages seem to correlate rather well with the status of the orchestra, with community orchestras consisting primarily of women, and top professional orchestras, such as the New York Philharmonic, supporting only a few.

Changes are also occurring in the United States among Native American groups, most notably Northwest Plains Grass Dance Traditional performers. Judith Vander and Orin Hatton have described these changes as having been motivated, in part, because of a need to revitalize this tradition and return it to its former status. ${ }^{41}$ Hatton traces the history of women drummers, showing a three-stage development: (1) the late nineteenth century, where women first assisted men as singers; (2) the early twentieth century, where they danced the traditional male dances in men's costumes imitating men's dance style; and finally (3) the present, where women are performing as drummers in all-female, as well as mixed groups, frequently composed of male and female family members. ${ }^{42}$ Hatton suggests that the family orientation of the mixed groups not only solves certain economic problems associated with pow-wow performance, but also keeps the older tradition alive through direct oral transmission. It seems clear then that social changes, with corresponding changes in what is culturally defined as appropriate behaviour for both men and women, do affect music performance and performance contexts.

Finally, although I have concentrated on women's performance here, I would like to stress that women, like men, are active participants in their social lives,

\footnotetext{
38Sarah Weiss, "Gender and Gender: The Female Gender Tradition in the Context of Present Day Javanese Society" (graduate paper, New York University, 1988).

39 Carol Neuls-Bates, "Women's Orchestras in the United States, 1925-45," in Women Making Music, 349-69.

40My female students at Eastman tell me that even today they will wear heavy shoes at a screened audition, will walk on stage with a "male" stride, and will breathe quietly so as not to reveal their sex. Many have told me of the judges' surprise at finding out they were female when they performed the final audition "in person.

41 Judith Vander, "The Song Repertoire of Four Shoshone Women: A Reflection of Cultural Movements and Sex Roles," Ethnomusicology 28, no. 1 (1982): 73-83; Orin T. Hatton, "In the Tradition: Grass Dance Musical Style and Female Pow-wow Singers," Ethnomusicology 30, no. 2 (1986): 197-222.

42Hatton, "In the Tradition: Grass Dance Musical Style and Female Pow-wow Singers," 209-10.
} 
and with men, engage in many varied activities where issues of power, authority, and control are negotiated on a daily, individual, and social basis. Thus, the future of gender studies concerning music depends not only upon an understanding of women's musical practices, per se, but also upon an understanding of the ongoing and infinitely varied interactions, interrelationships, and interdependencies of men and women and how these are enacted musically.

\begin{abstract}
In many societies, musical roles are divided along gender lines: women sing and men play. Men also sing and women sometimes play; yet, unlike men, women who play often do so in contexts of sexual and social marginality. This essay surveys the literature on women's use of musical instruments in a variety of social and cultural contexts and presents some contemporary anthropological theories regarding the interrelationship between social structure and gender stratification. The author concludes that women's use of musical instruments is related to broader issues of social and gender structure, and that changes in the ideology of these structures often reflect changes that affect women as performers.
\end{abstract}

